\title{
Student Attitudes to Traditional and Online Methods of Delivery
}

\author{
Lily Wong and Michelle Fong \\ Victoria University, Melbourne, Australia
}

lily.wong@vu.edu.au michelle.fong@vu.edu.au

\begin{abstract}
Rapid developments in education technology have provided educators and students new options in a constantly changing, competitive teaching and learning environment. As the number of online teaching resources continue to increase, research into student attitudes toward traditional and online methods of delivery is important in order to determine whether the increased usage of technology in the curriculum has been beneficial to their learning. This paper investigates the student perceptions of these two methods of delivery in a first-year introductory accounting unit in a number of key areas. These include their perceptions of learning effectiveness, motivation and impact on assessment outcomes. The importance of social interaction and their preference for online learning is also covered. This preliminary analysis of student attitudes will determine whether there are statistically significant differences between face-to-face and online learning options and preference for online learning technology between gender groups. In addition, this paper investigates whether there are statistically significant relationships between face-to-face or online learning options and preference for online learning technology in gender groups.
\end{abstract}

Keywords: student attitudes, online learning, technology, face-to-face, effectiveness, e-learning

\section{Introduction}

To remain globally competitive, universities are incorporating greater use of information and communications technologies (ICT) into their curriculum to provide students with more online learning options via the university's Learning Management System (LMS). Many have adopted a 'blended learning' approach to deliver course content which combines traditional face-to-face teaching augmented with online teaching resources. This has been a popular approach as it provides students greater flexibility and increased accessibility to a diverse range of teaching materials to support their learning. With the increasing pressure to provide more e-learning options to students, it is important to consider student attitudes towards this shift away from the traditional face-to-face to online delivery. According to Ong and Lai (2006), gaining insight into the learners

Material published as part of this publication, either on-line or in print, is copyrighted by the Informing Science Institute. Permission to make digital or paper copy of part or all of these works for personal or classroom use is granted without fee provided that the copies are not made or distributed for profit or commercial advantage AND that copies 1) bear this notice in full and 2) give the full citation on the first page. It is permissible to abstract these works so long as credit is given. To copy in all other cases or to republish or to post on a server or to redistribute to lists requires specific permission and payment of a fee. Contact Publisher@InformingScience.org to request redistribution permission. motivation and attitudes to using technology may influence the level of elearning utilisation. The fact that student perceptions of the Learning Management System and its online materials may influence their level of engagement has been acknowledged by Basioudis, De Lange, Suwardy, and Wells (2012). These factors may impact upon student learning outcomes and their overall learning experience. In recent reviews 
of research in accounting education by Apostolou, Hassell, Rebele, and Watson (2011) and Apostolou, Dorminey, Hassell, and Watson (2013), the need for more empirical studies into the effectiveness of using technology in accounting education was highlighted.

This paper aims to contribute to this area of research by providing an insight into how students in a first-year introductory accounting unit perceive these changes based on their gender and whether it has an impact on learning effectiveness, motivation, and assessment outcomes.

\section{Literature Review}

In a study conducted by Ginns and Ellis (2007) the increasing pressure for greater integration of new technology into the student learning experience was acknowledged. Wells, de Lange, and Fieger (2008) found that the use of technology in educational settings assists in the achievement of learning outcomes. Buzzetto-More (2008) and Sanders and Morrison-Shetlar (2002) reported that student attitudes toward technology are influential in determining the educational benefits of online learning resources and experiences. Results from an investigation of WebCT Course Management Statistical Tools in this first-year introductory accounting unit revealed a positive relationship between the level of student engagement with online resources and their overall academic result. Across the key online activities measured, the time spent on each activity was considerably longer for higher achieving students in comparison to failed students (L. Wong, 2013).

The notion that blended learning can positively impact upon assessment outcomes has been found in a number of studies. Dowling, Godfrey, and Gyles (2003) analysed whether a hybrid, flexible teaching method, in comparison to traditional face-to-face lectures, improved learning outcomes. Their results suggested a positive change in student grades when the traditional approach was used in combination with extensive use of multi-media resources. Dunbar (2004) described and analysed the transformation of a face-to face course to an online course using an online learning platform, WebCT. The survey asked students about their preference to have a live instructor or to take the class online. The majority of students responded that they would rather take the online class. Aisbitt and Sangster (2005) described the implementation and effectiveness of a new online assessment system designed to encourage and reinforce the learning of basic principles in an introductory accounting course. A positive correlation was found between student performance in the online assessments and in their final examination. Mcdowall and Jackling (2006) analysed student perceptions of the usefulness of a Computer-Assisted Learning (CAL) package in learning accounting concepts and its influence on students' academic performance. Their results showed that positive perceptions of the usefulness of CAL significantly influenced performance. The change in the method of instruction enabled a more effective use of the technology, potentially increased teaching effectiveness and improved academic performance. Potter and Johnston (2006) investigated the association between student use of a unique, interactive, online learning system, MarlinaLS, and their learning outcomes. The results showed that students' use of the new system was positively associated with both their examination performance and the internal assessment result.

In their research on the use of ICT by undergraduate students and their views regarding Internet use in accounting programs, Marriott, Marriott, and Selwyn (2004) raised some concerns relating to online learning. Students expressed their preference for a face-to-face form of educational experience and indicated that they would endorse only Internet usage that supported the traditional delivery of courses, as they valued the social interaction and the communication skills they acquired from the classroom environment. Decreased social contact and the potential isolation of learning on their own was a primary concern identified in this study. Student preference for a more traditional style of teaching was also reported in a more recent study by Osgerby (2013), which investigated students' perception of the introduction of a blended learning environment and concluded that whilst students appeared to have a positive attitude to the adoption of an organised 
and well-resourced ICT based learning process, they preferred face-to-face lectures and step-bystep instruction. Smith and Greene (2013) examined the use of e-learning technologies to enhance learning. While the benefits of e-learning were recognized by the participants, these were somewhat compromised by the technological difficulties experienced. This study acknowledged that, overall, the current literature supports the view that e-learning in higher education enhances the teaching and learning experiences.

Research conducted by Naaj, Nachouki, and Ankit (2012) considered student satisfaction an important factor in measuring the quality of blended learning. Their study proposed that students' satisfaction is influenced by a combination of factors that include the instructor, the technology, class management, interaction, and instruction. In their study analysing student patterns of access to instructional resources provided in an online course environment, Murray, Pérez, Geist, and Hedrick (2012) point out that as the number of students learning online increases, the greater the importance of understanding how students engage and interact with course content becomes.

Previous studies on gender imbalance in attitudes towards using technology for learning remained inconclusive. Vale and Leder (2004), Kaino (2008) and Yau and Cheng (2012) found that male students are more willing to embrace learning technology compared to female students and they attributed this imbalance to the lack of a gender inclusive curriculum in online learning technology. These researchers emphasised the importance of a technology training course for female students in preparing them for using this mode of learning. S. L. Wong and Hanafi (2007) found that female participants possessed a higher level of confidence and improved attitude after undergoing a technology training course. Arbaugh (2000), on the other hand, found that male students encountered more difficulty in using learning technology for class participation compared to their female counterparts. However, a study by Shaw and Marlow (1999) did not reveal any gender imbalance in attitudes towards using technology for learning.

Students in their first year of university have distinct learning needs arising from the social and academic transition they are experiencing. From multiple starting points, all students are on a journey to becoming self-managing and self-directed learners and the first-year curriculum should help get them there (Nelson, Kift, Humphreys, \& Harper, 2006). The student cohort for this introductory accounting unit is typically from a lower socio-economic background. For most of these students, it is a necessity to combine work commitments with their study. A large proportion of the students sampled in this study are from a non-accounting accounting majors with little or no prior studies in accounting. The introduction of e-learning to augment traditional face-to-face delivery provides a greater degree of flexibility in providing support for the diverse demands of these students.

\section{Methodology}

The aim of this paper is to investigate students' attitudes toward traditional and online methods of delivery in a first-year introductory accounting unit. The findings reported are based on a case study conducted over four consecutive semesters commencing Semester 1/2010 through to Semester 2/2011. In Semester 1/2010, students were introduced to three new online learning options to complement traditional face-to-face lectures and tutorials.

The first of these options was the viewing of recorded lectures via Lectopia, an automated lecture recording and web publishing tool. Students had immediate access to an audio-visual recording of a lecture, which generally comprised lecture slides, commentary and illustrations using links to websites where relevant. Whilst this could be downloaded and viewed at their convenience, it did not however provide for any student interaction via a discussion board or any other online chat facilities. 
The second option enabled students the opportunity to enrol and actively participate in online tutorials via Elluminate Live which is an online collaborative session. To join the online tutorial they were required to login to the Elluminate Live website each week at a regular designated time. These sessions were conducted by the unit coordinator. The transfer of knowledge and review of tutorial content was facilitated through shared files or a shared whiteboard where students could also take control of the screen for direct input. Interaction between the online tutor and students was through an onscreen dialogue sidebar or speaking directly via microphone or headset. Each of the Elluminate Live tutorials were recorded and posted on WebCT by the end of each week.

The third option allowed students to download and review the audio-visual content from the Elluminate Live tutorials. As with the first option of the recorded lectures, this was a passive viewing option. Access to all these additional online resources was via the unit website on WebCT.

There are many other supplementary resources available to students accessible from WebCT that include instructional videos and modules covering content which students perceive to be more difficult to understand; however, this is beyond the scope of this particular paper.

This preliminary analysis of student attitudes will determine whether there are statistically significant differences between face-to-face and online learning options and preference for online learning technology between gender groups. In addition, this paper examines whether there are statistically significant correlations between face-to-face or online learning options and preference for online learning technology in gender groups.

\section{The Survey}

A survey questionnaire was designed to gauge student perceptions of learning effectiveness, motivation, and impact on assessment outcomes for face-to-face or online learning options. The importance of social interaction and student preference for online learning was also assessed. The survey instrument comprised three sections. The first section provided a profile of the socioeconomic and educational background of the sample. This paper focuses on the second section, which rated the students' study preferences toward the traditional face-to-face lectures and tutorials, as well as new online teaching options. Each of the options were listed and students were asked to rate the effectiveness of each in assisting their learning in this subject by using a four point rating scale. The survey questionnaire was distributed to students in the last lecture at the end of each semester and student participation was voluntary. Almost all students attending these sessions participated in the survey. The total number of surveys completed was 515 , of which 323 were usable for this paper.

The students surveyed were from various lecture streams and tutorial groups. Both day-time and evening students were represented in this sample. The vast majority of students in this study have no interest in majoring in accounting and have little or no previous accounting knowledge.

Survey data was collated and entered into IBM SPSS Statistics 21 software for statistical analysis. Student responses were collected over four consecutive semesters commencing from Semester $1 / 2010$ through to Semester 2/2011. The data was accumulated over this period and the 323 usable surveys form the basis of the statistical analysis which follows. Table 1 provides a demographic profile of the survey participants. 
Table 1 - Demographic Profile of Survey Participants

\begin{tabular}{|l|c|}
\hline Number of Survey Participants & \\
\hline Sample Size & $\mathrm{n}=323$ \\
\hline Gender & $\mathbf{\%}$ \\
\hline Male & 47 \\
\hline Female & 53 \\
\hline Mode of Study & $\mathbf{\%}$ \\
\hline Full-Time & 88 \\
\hline Which year of study are you in? & $\mathbf{\%}$ \\
\hline 1st & 65 \\
\hline Are your major studies in Accounting? & $\mathbf{\%}$ \\
\hline No & 79 \\
\hline Studied Accounting Previously & $\mathbf{\%}$ \\
\hline No & 68 \\
\hline Work and Study & $\mathbf{\%}$ \\
\hline Not working & 30 \\
\hline Working and studying & 70 \\
\hline Age & $\mathbf{\%}$ \\
\hline Less than 20 years & 38 \\
\hline 20 to 29 years & 55 \\
\hline 30 years or older & 7 \\
\hline
\end{tabular}

\section{Profile of Participants}

In this sample, female students represented a slightly higher proportion than male students. The vast majority of students, $88 \%$, were studying in full-time mode, and for a significant proportion of these participants, $65 \%$ are in their first year of study at university. A minority of students enrolled in this compulsory accounting unit, $21 \%$ are accounting majors and a large proportion of these students, $68 \%$, have no prior studies in accounting. A significant majority of these students, $70 \%$, are working and studying. The dominant age group are those students less than 20 and those between 20 to 29 years old. These two younger groups combined represent $93 \%$ of surveyed students in comparison to mature students aged 30 years or older who account for only $7 \%$ of this group.

\section{Statistical Analysis}

This paper utilises mean comparisons and nonparametric Wilcoxon Rank Sum test to determine whether there are significant differences between the male and female students studying in firstyear accounting. In addition, Pearson's r Correlation method, which measures the strength of the linear relationship between two variables (Bereson, Levine, Krehbiel, Timothy, \& Stephan, 2013) was used to identify the relationships between face-to-face or online learning options and preference for online learning technology in gender groups. This correlation measure is important for providing insights into the profile of the male and female students studying the first-year accounting unit in relation to face-to-face and online learning options, and preference for online learning technology.

For investigating the relationships between face-to-face or online learning strategies and preference for online learning technology in gender groups, responses collected from the survey were computed into equally weighted summated scores for each relevant construct/attribute. In other words, the score for each construct/attribute constitutes an average of all the relevant item scores (obtained through responses to the questions in the survey). Because each item bears equal 
weight and importance in a construct, this summation method is an appropriate estimator of the attribute. This method has been found to be as effective as other weighted combination by McDonald (1997).

Table 2 shows the items that were transformed into relevant constructs in this research paper:

Table 2: Items Relevant To Each Construct

\begin{tabular}{|l|l|}
\hline ITEMS (QUESTIONS): & CONSTRUCTS: \\
\hline $\begin{array}{l}\text { 1. EFFECTIVENESS OF LEARNING MODE: } \\
\text { 1a. Lectures - face to face }\end{array}$ & $\begin{array}{l}\text { Face to face learn- } \\
\text { ing mode effective- } \\
\text { ness }\end{array}$ \\
\hline $\begin{array}{l}\text { 1b. } \text { Lectopia - recorded lectures } \\
\text { 1d. Elluminate - recorded tutorials } \\
\text { 1e. Elluminate Live - participating in online tutorials }\end{array}$ & $\begin{array}{l}\text { Online learning } \\
\text { mode effectiveness }\end{array}$ \\
\hline $\begin{array}{l}\text { 2. MOTIVATED BY LEARNING MODE: } \\
\text { 2a. Lectures - face to face } \\
\text { 2c. Tutorials - face to face }\end{array}$ & $\begin{array}{l}\text { Motivated by Face } \\
\text { to face learning } \\
\text { mode }\end{array}$ \\
\hline $\begin{array}{l}\text { 2b. Lectopia - recorded lectures } \\
\text { 2d. Elluminate - recorded tutorials } \\
\text { 2e. Elluminate Live - participating in online tutorials }\end{array}$ & $\begin{array}{l}\text { Motivated by online } \\
\text { learning mode }\end{array}$ \\
\hline $\begin{array}{l}\text { 3. IMPACT OF LEARNING MODE ON ASSESSMENT OUTCOME: } \\
\text { 3a. Lectures - face to face } \\
\text { 3c. Tutorials - face to face }\end{array}$ & $\begin{array}{l}\text { Impact of Face to } \\
\text { face learning mode } \\
\text { on assessment out- } \\
\text { come }\end{array}$ \\
\hline $\begin{array}{l}\text { 3b. Lectopia - recorded lectures } \\
\text { 3d. Elluminate - recorded tutorials } \\
\text { 3e. Elluminate Live - participating in online tutorials }\end{array}$ & $\begin{array}{l}\text { Impact of online } \\
\text { learning mode on } \\
\text { assessment out- } \\
\text { come. }\end{array}$ \\
\hline $\begin{array}{l}\text { 4. IMPORTANCE OF INTERACTION: } \\
\text { 4a. social interaction in tutorials and lectures } \\
\text { 4c. having a time and place for your tutorials and lectures on campus }\end{array}$ & $\begin{array}{l}\text { Importance of inter- } \\
\text { action }\end{array}$ \\
\hline $\begin{array}{l}\text { 5. PREFERENCE FOR ONLINE LEARNING TECHNOLOGY } \\
\text { 5f. have more technology used in this unit }\end{array}$ & $\begin{array}{l}\text { Prefer to use online } \\
\text { learning technology }\end{array}$ \\
\hline fe. less technology used in this unit & $\begin{array}{l}\text { online learning } \\
\text { technology }\end{array}$ \\
\hline
\end{tabular}




\section{Results and Discussion}

\section{Means Comparison and Wilcoxon Rank Sum Test}

Table 3 shows the means comparison of each construct (that is, face-to-face and online learning options, and online learning technology preference) between the male and female students studying first-year accounting. The sample size for each construct is denoted by ' $n$ ' in Table 3 . The last column in this table shows the results of the nonparametric independent test using Wilcoxon Rank Sum Test to determine whether there is a significant difference between male and female for each of these constructs. To gauge the students' perception of each of these constructs, a four point rating scale was used with $1=$ lowest rating and $4=$ highest rating. Sample sizes of all constructs do not include responses from respondents who do not find the question (or item) applicable to their situation and answered 'not applicable' in the questionnaire. This response would be the option available to respondents if they did not use any of the online resources available, namely the viewing of recorded lectures, the viewing of recorded tutorials or actively participating in the online tutorials.

The mean scores calculated for each of these options are shown in Table 3 below.

Table 3: Means Comparison and Wilcoxon Rank Sum Test

\begin{tabular}{|l|c|c|l|}
\hline Constructs: & $\begin{array}{c}\text { Male } \\
\text { Mean Scores } \\
\text { (Mean Male }\end{array}$ & $\begin{array}{c}\text { Female } \\
\text { Mean Scores } \\
\text { (Mean Female })\end{array}$ & $\begin{array}{c}\text { Wilcoxon } \\
\text { Rank Sum Test }\end{array}$ \\
\hline $\begin{array}{l}\text { Face to face learning mode ef- } \\
\text { fectiveness }\end{array}$ & $\begin{array}{c}3.35 \\
(\mathrm{n}=150)\end{array}$ & $\begin{array}{c}3.34 \\
(\mathrm{n}=164)\end{array}$ & $\begin{array}{l}\text { No significant differences } \\
\text { between male \& female }\end{array}$ \\
\hline $\begin{array}{l}\text { Online learning mode effective- } \\
\text { ness }\end{array}$ & $\begin{array}{c}2.45 \\
(\mathrm{n}=74)\end{array}$ & $\begin{array}{c}2.49 \\
(\mathrm{n}=62)\end{array}$ & $\begin{array}{l}\text { No significant differences } \\
\text { between male \& female }\end{array}$ \\
\hline $\begin{array}{l}\text { Motivated by face to face learn- } \\
\text { ing mode }\end{array}$ & $\begin{array}{c}3.15 \\
(\mathrm{n}=150)\end{array}$ & $\begin{array}{c}3.14 \\
(\mathrm{n}=165)\end{array}$ & $\begin{array}{l}\text { No significant differences } \\
\text { between male \& female }\end{array}$ \\
\hline $\begin{array}{l}\text { Motivated by online learning } \\
\text { mode }\end{array}$ & $\begin{array}{c}2.35 \\
(\mathrm{n}=73)\end{array}$ & $\begin{array}{c}2.30 \\
(\mathrm{n}=67)\end{array}$ & $\begin{array}{l}\text { No significant differences } \\
\text { between male \& female }\end{array}$ \\
\hline $\begin{array}{l}\text { Impact of face to face learning } \\
\text { mode on assessment outcome }\end{array}$ & $\begin{array}{c}3.23 \\
(\mathrm{n}=147)\end{array}$ & $\begin{array}{c}3.29 \\
(\mathrm{n}=162)\end{array}$ & $\begin{array}{l}\text { No significant differences } \\
\text { between male \& female }\end{array}$ \\
\hline $\begin{array}{l}\text { Impact of online learning mode } \\
\text { on assessment outcome. }\end{array}$ & $\begin{array}{c}1.57 \\
(\mathrm{n}=75)\end{array}$ & $\begin{array}{c}1.28 \\
(\mathrm{n}=60)\end{array}$ & $\begin{array}{l}\text { No significant differences } \\
\text { between male \& female }\end{array}$ \\
\hline $\begin{array}{l}\text { Importance of social interaction } \\
\text { in tutorials and lectures }\end{array}$ & $\begin{array}{c}3.19 \\
(\mathrm{n}=149)\end{array}$ & $\begin{array}{c}1.18 \\
(\mathrm{n}=165)\end{array}$ & $\begin{array}{l}\text { No significant differences } \\
\text { between male \& female }\end{array}$ \\
\hline $\begin{array}{l}\text { Prefer to use online learning } \\
\text { technology }\end{array}$ & $\begin{array}{c}1.99 \\
(\mathrm{n}=139)\end{array}$ & $\begin{array}{l}\text { No significant differences } \\
\text { between male \& female }\end{array}$ \\
\hline $\begin{array}{l}\text { Do not prefer to use online } \\
\text { learning technology }\end{array}$ & $\begin{array}{c}1.68 \\
(\mathrm{n}=167)\end{array}$ & $\begin{array}{l}\text { No significant differences } \\
\text { between male \& female }\end{array}$ \\
\hline
\end{tabular}


The results from Wilcoxon Rank Sum tests show that there were no significant differences between face-to-face or online learning options and preference for online learning technology between male and female students studying first-year accounting. Both these groups on average found the face-to-face learning mode effective $\left(\operatorname{Mean}_{\text {Male }}=3.35\right.$ and Mean $\left._{\text {Female }}=3.34\right)$ and were quite motivated by this traditional mode of delivery $\left(\mathrm{Mean}_{\mathrm{Male}}=3.15\right.$ and $\left.\mathrm{Mean}_{\mathrm{Female}}=3.14\right)$. In addition, each group found the face-to-face learning mode effective in influencing their assessment outcome $\left(\mathrm{Mean}_{\mathrm{Male}}=3.23\right.$ and $\left.\mathrm{Mean}_{\mathrm{Female}}=3.29\right)$. Compared to the face-to-face learning mode, the mean scores for the online learning mode were lower in learning effectiveness (MeanMale $=2.45$ and Mean $\left._{\text {Female }}=2.49\right)$, motivation $\left(\operatorname{Mean}_{\text {Male }}=2.35\right.$ and Mean $\left._{\text {Female }}=2.3\right)$ and assessment outcome $\left(\operatorname{Mean}_{\text {Male }}=1.59\right.$ and Mean $\left.n_{\text {Female }}=1.28\right)$. Both male and female students attached high importance to opportunities for social interaction in their learning $\left(\mathrm{Mean}_{\mathrm{Male}}=3.19\right.$ and Mean $_{\text {Female }}=3.18$ ).

The average scores of students who prefer to use more online learning technology were quite low $\left(\mathrm{Mean}_{\text {Male }}=1.97\right.$ and Mean $\left.\mathrm{Female}=1.99\right)$. With the rating scale using 1 for Strongly Agree and 2 for Disagree, these results indicate disagreement towards more reliance or total reliance on online learning for this unit. Simultaneously, the average score of students who do not prefer to use online learning technology $\left(\mathrm{Mean}_{\mathrm{Male}}=1.76\right.$ and $\left.\mathrm{Mean}_{\mathrm{Female}}=1.68\right)$ using the aforementioned rating scale indicate disagreement towards reduction or total elimination of online learning technology in the teaching of this first-year accounting unit.

These responses are consistent with the results from the final question on the survey, "Overall, I am happy with the level of technology used"- which revealed an overwhelming majority of these students (cumulative of $92.4 \%$ as per Table 4) agreed or strongly agreed that they were happy with the current level of technology used. In other words, these students disagree to having more or lesser technology implemented in this unit. Table 4 shows the frequency distribution of responses to this question.

Table 4: Frequency Distribution Student Responses to Question - "Overall, I am happy with the level of technology used"

\begin{tabular}{|l|c|c|c|}
\hline Responses & Frequency & Percentage & Cumulative \\
\hline Strongly disagree & 3 & $0.95 \%$ & $7.6 \%$ \\
\hline Disagree & 21 & $6.67 \%$ & \multirow{2}{*}{$92.4 \%$} \\
\hline Agree & 180 & $57.14 \%$ & $\mathbf{1 0 0} \%$ \\
\hline Strongly agree & 111 & $35.24 \%$ & $\mathbf{1 0 0 \%}$ \\
\hline Total & $\mathbf{3 1 5}$ & & \\
\hline
\end{tabular}




\section{Pearson's r Correlation}

Table 5 shows the results from Pearson's r Correlation test.

Table 5: Pearson's r Correlation Test Results

\begin{tabular}{|c|c|c|c|}
\hline Constructs: & $\begin{array}{l}\text { Preference for online } \\
\text { learning technology }\end{array}$ & $\begin{array}{c}\text { Male } \\
\text { Correlation coef- } \\
\left.\text { ficient ( } r_{\text {Male }}\right)\end{array}$ & $\begin{array}{c}\text { Female } \\
\text { Correlation coef- } \\
\text { ficient }\left(\mathbf{r}_{\text {Female }}\right)\end{array}$ \\
\hline \multirow[t]{2}{*}{$\begin{array}{l}\text { 1.Face to face learning } \\
\text { mode effectiveness }\end{array}$} & $\begin{array}{l}\text { Prefer to use online } \\
\text { learning technology }\end{array}$ & $-0.14 *$ & $-0.142 *$ \\
\hline & $\begin{array}{l}\text { Do not prefer to use online } \\
\text { learning technology }\end{array}$ & Not significant & Not significant \\
\hline \multirow[t]{2}{*}{$\begin{array}{l}\text { 2.Online learning mode } \\
\text { effectiveness }\end{array}$} & $\begin{array}{l}\text { Prefer to use online } \\
\text { learning technology }\end{array}$ & $0.297^{* *}$ & $0.295^{* *}$ \\
\hline & $\begin{array}{l}\text { Do not prefer to use online } \\
\text { learning technology }\end{array}$ & 0.194* & Not significant \\
\hline \multirow[t]{2}{*}{$\begin{array}{l}\text { 3.Motivated by face to } \\
\text { face learning mode }\end{array}$} & $\begin{array}{l}\text { Prefer to use online } \\
\text { learning technology }\end{array}$ & Not significant & Not significant \\
\hline & $\begin{array}{l}\text { Do not prefer to use online } \\
\text { learning technology }\end{array}$ & Not significant & Not significant \\
\hline \multirow[t]{2}{*}{$\begin{array}{l}\text { 4.Motivated by online } \\
\text { learning mode }\end{array}$} & $\begin{array}{l}\text { Prefer to use online } \\
\text { learning technology }\end{array}$ & Not significant & $0.291^{* *}$ \\
\hline & $\begin{array}{l}\text { Do not prefer to use online } \\
\text { learning technology }\end{array}$ & Not significant & Not significant \\
\hline \multirow{2}{*}{$\begin{array}{l}\text { 5.Impact of face to face } \\
\text { learning mode on as- } \\
\text { sessment outcome }\end{array}$} & $\begin{array}{l}\text { Prefer to use online } \\
\text { learning technology }\end{array}$ & Not significant & Not significant \\
\hline & $\begin{array}{l}\text { Do not prefer to use online } \\
\text { learning technology }\end{array}$ & Not significant & Not significant \\
\hline \multirow{2}{*}{$\begin{array}{l}\text { 6.Impact of online } \\
\text { learning mode on as- } \\
\text { sessment outcome. }\end{array}$} & $\begin{array}{l}\text { Prefer to use online } \\
\text { learning technology }\end{array}$ & $0.247 * *$ & $0.294^{* *}$ \\
\hline & $\begin{array}{l}\text { Do not prefer to use online } \\
\text { learning technology }\end{array}$ & Not significant & Not significant \\
\hline \multirow[t]{2}{*}{$\begin{array}{l}\text { 7.Importance of inter- } \\
\text { action }\end{array}$} & $\begin{array}{l}\text { Prefer to use online } \\
\text { learning technology }\end{array}$ & $-0.266^{* * *}$ & $-0.173 * *$ \\
\hline & $\begin{array}{l}\text { Do not prefer to use online } \\
\text { learning technology }\end{array}$ & Not significant & Not significant \\
\hline
\end{tabular}

Note: $* \mathrm{p}<0.1, * * \mathrm{p}<0.05, * * * \mathrm{p}<0.01$

Several of the correlation test results in Table 5 showed no significant differences. Except for the relationship between importance of interaction and preferring to use online learning technology which was significant at $1 \%$, other relationships were significant at $5 \%$ or $10 \%$ indicating weak or moderate relationship between the variables. For example, face-to-face learning mode has an inverse relationship with preferring to use online learning technology and this suggests that students who prefer to use online learning technology tend to find face-to-face learning mode less effective. However, the correlation coefficient $\left(\mathrm{r}_{\text {Male }}=-0.14\right.$ and $\mathrm{r}_{\mathrm{Female}}=-0.142$, both at $\left.\mathrm{p}<0.10\right)$ 
suggests this relationship is weak with low degree of correlation between these variables. For online learning mode, it has a moderate degree of association with preferring to use online learning technology $\left(r_{\text {Male }}=0.297\right.$ and $r_{F e m a l e}=0.295$, both at $\left.p<0.05\right)$ regardless of gender. The test on the relationship between online learning mode effectiveness and preferring not to use online learning technology shows a weak positive relationship for male students studying first-year accounting ( $\mathrm{r}_{\text {Male }}=0.194$ at $\left.\mathrm{p}<0.10\right)$, this relationship was not significant for the female students. Motivated by online learning mode has a moderate positive relationship with preferring to use online learning technology for female students studying in this first-year accounting unit $\left(\mathrm{r}_{\mathrm{Female}}=\right.$ 0.291 at $p<0.05$ ) but this relationship was not significant for the male students. Impact of online learning mode on assessment outcome has a moderate positive association with preferring to use online learning technology $\left(\mathrm{r}_{\mathrm{Male}}=0.247\right.$ and $\mathrm{r}_{\mathrm{Female}}=0.294$, both at $\left.\mathrm{p}<0.05\right)$ regardless of gender.

The relationship between the importance of interaction and preferring to use online learning technology was found to be statistically significant particularly for the male students $\left(\mathrm{r}_{\mathrm{Male}}=-0.266\right.$ at $\mathrm{p}<0.01)$ as compared to the female $\left(\mathrm{r}_{\mathrm{Female}}=-0.173\right.$ at $\left.\mathrm{p}<0.05\right)$. These inverse relationships indicate that those who prefer to use online learning technology tend to place less importance on opportunities for social interaction. In this study, male students preferring online learning technology tend to place comparatively less importance on opportunities for interaction than female students.

The results in Table 3 are consistent with studies by Marriott et al. (2004) and Osgerby (2013) who found that whilst students embraced a blended learning environment, they indicated a stronger preference for retaining the traditional method of delivery. This table suggests that there is no significant gender imbalance in attitudes towards using face-to-face and online learning options and supports the finding from Shaw and Marlow (1999) on the absence of gender imbalance. When these attitudes were further analysed based on preference for online learning technology, the Pearson's r Correlation test (results in Table 5) revealed both gender groups preferring to use online learning technology emphasised the importance of interaction in this mode.

\section{Conclusion}

The aim of this preliminary analysis of student attitudes was to determine whether there were statistically significant differences between face-to-face and online learning options and preference for online learning technology between gender groups. The results from Wilcoxon Rank Sum tests show that there were no significant differences between face-to-face or online learning options and preference for online learning technology between male and female students studying first-year accounting. Both these groups on average found the face-to-face learning mode effective and were quite motivated by this traditional mode of delivery. In addition, each group found the face-to-face learning mode effective in influencing their assessment outcome. Compared to the face-to-face learning mode, the mean scores for the online learning mode were lower in learning effectiveness, motivation, and assessment outcome. Both male and female students attached high importance to opportunities for social interaction in their learning.

The average scores of students who prefer to use more online learning technology were quite low which indicates disagreement towards more reliance or total reliance on online learning for this unit. Simultaneously, the average score of students who do not prefer to use online learning technology indicates disagreement towards reduction or total elimination of online learning technology in the teaching of this first-year accounting unit. An overwhelming majority of these students agreed or strongly agreed that they were happy with the current level of technology used.

Pearson's $r$ Correlation Test was conducted to determine whether there are statistically significant relationships between face-to-face or online learning options and preference for online learning technology in gender groups. 
The key findings show that the effect of the face-to-face learning mode has an inverse relationship with preferring to use online learning technology and this suggests that students who prefer to use online learning technology tend to find face-to-face learning mode less effective. The effect of the online learning mode has a moderate degree of association with preferring to use online learning technology.

It was also found that those motivated by the online learning mode have a moderate positive relationship with preferring to use online learning technology for female students studying in this first-year accounting unit but this relationship was not significant for the male students.

The results showed that the impact of the online learning mode on assessment outcome had a moderate positive association with preferring to use online learning technology regardless of gender. However, there is no relationship between impact of online learning mode on assessment outcome and do not prefer to use online learning technology for both the gender groups.

Finally, the analysis revealed that there are significant inverse relationships between the importance of social interaction and the preference to use online learning technology, particularly for the male students. These inverse relationships indicate that those prefer to use online learning technology tend to place less importance on opportunities for social interaction. In this study, male students preferring online learning technology tend to place comparatively less importance on opportunities for interaction than female students.

With the rapidly changing nature of accounting education, Rebele (2002) highlighted the importance of research specific to the effective use of technology in accounting education. In a review of more recent literature by Apostolou et al. (2011) and Apostolou et al. (2013), the call for more empirical studies into the effectiveness of using technology in accounting education was reiterated. By addressing some of the issues relating to student attitudes toward traditional and online methods of delivery, these findings aim to contribute to this current gap in research.

\section{References}

Aisbitt, S., \& Sangster, A. (2005). Using internet-based on-line assessment: A case study. Accounting Education, 14(4), 383-394.

Apostolou, B., Dorminey, J. W., Hassell, J. M., \& Watson, S. F. (2013). Accounting education literature review (2010-2012). Journal of Accounting Education, 31(2), 107-161.

Apostolou, B., Hassell, J. M., Rebele, J., \& Watson, S. F. (2011). Accounting education literature review (2006-2009). Journal of Accounting Education, 28(3-4), 145-197. doi: doi:10.1016/j.jaccedu.2011.2011.08.001

Arbaugh, J. B. (2000). An exploratory study of the effects of gender on student learning and class particupation in an Internet-based MBA course. Management Learning, 31, 503-519.

Basioudis, I. G., De Lange, P., Suwardy, T., \& Wells, P. (2012). Accounting students' perceptions of a learning management system: An international comparison. Accounting Research Journal, 25(2), $72-$ 86.

Bereson, M., Levine, L., Krehbiel, D. M., Timothy, C., \& Stephan, D. F. (2013). Basic business statistics: concepts and applications. New South Wales, Australia: Pearson.

Buzzetto-More, N. A. (2008). Student perceptions of various e-learning components. Interdisciplinary Journal of E-Learning and Learning Objects, 4(1), 113-135. Retrieved from http://www.ijello.org/Volume4/IJELLOv4p113-135Buzzetto413.pdf

Dowling, C., Godfrey, J. M., \& Gyles, N. (2003). Do hybrid flexible delivery teaching methods improve accounting students' learning outcomes? Accounting Education, 12(4), 373-391.

Dunbar, A. E. (2004). Genesis of an online course. Issues in Accounting Education, , 19(3), 321-343. 
Ginns, P., \& Ellis, R. (2007). Quality in blended learning: Exploring the relationships between on-line and face-to-face teaching and learning. The Internet and Higher Education, 10(1), 53-64.

Kaino, L. M. (2008). Technology in learning: Narrowing the gender gap? Eurasia Journal of Mathematics, Science and Technology Education, 4(3), 263-268.

Marriott, N., Marriott, P., \& Selwyn, N. (2004). Accounting undergraduates' changing use of ICT and their views on using the Internet in higher education - A research note. Accounting Education, 13(4 supp 1), $117-130$.

McDonald, R. P. (1997). Haldane's lungs: A case study in path analysis. Multivariate Behavioural Research, 32, 1-38.

Mcdowall, T., \& Jackling, B. (2006). The impact of computer-assisted learning on academic grades: An assessment of students' perceptions. Accounting Education, 15(4), 377-389.

Murray, M., Pérez, J., Geist, D., \& Hedrick, A. (2012). Student interaction with online course content: Build it and they might come. Journal of Information Technology Education: Research, 11(1), 125140. Retrieved from http://www.jite.org/documents/Vol11/JITEv11p125-140Murray1095.pdf

Naaj, M. A., Nachouki, M., \& Ankit, A. (2012). Evaluating student satisfaction with blended learning in a gender-segregated environment. Journal of Information Technology Education: Research,, 11, 185200. Retrieved from http:/www.jite.org/documents/Vol11/JITEv11p185-200AbouNaaj0979.pdf

Nelson, K., Kift, S., Humphreys, J., \& Harper, W. (2006). A blueprint for enhanced transition: Taking an holistic approach to managing student transition into a large university. Proceedings of the First Year in Higher Education Conference, Gold Coast, Australia. Copyright 2006 (please consult author).

Ong, C. S., \& Lai, J. Y. (2006). Gender differences in perceptions and relationships among dominants of elearning acceptance. Computers in Human Behavior, 22(5), 816-829.

Osgerby, J. (2013). Students' perceptions of the introduction of a blended learning environment: An exploratory case study. Accounting Education, 22(1), 85-99.

Potter, B. N., \& Johnston, C. G. (2006). The effect of interactive on-line learning systems on student learning outcomes in accounting. Journal of Accounting Education, 24(1), 16-34.

Rebele, J. E. (2002). Accounting education's uncertain environments: Descriptions and implications for accounting programmes and accounting education research. Accounting Education, 11(1), 3-25.

Sanders, D., \& Morrison-Shetlar, A. (2002). Student attitudes toward web-enhanced instruction in an introductory biology course. Journal of Research on Computing in Education, 33(3), 251-262.

Shaw, G., \& Marlow, N. (1999). The role of student learning styles, gender, attitudes and perceptions on information and communication technology assisted learning. Computers and Education, 33(4), 223234.

Smith, J. J., \& Greene, H. C. (2013). Pre-service teachers use e-learning technologies to enhance their learning. Journal of Information Technology Education: Research, 12, 121-140. Retrieved from http://www.jite.org/documents/Vol12/JITEv12ResearchP121-140Smith1223.pdf

Vale, C. M., \& Leder, G. C. (2004). Student views of computer-based mathematics in the middle years: Does gender make a difference? Educational Studies in Mathematics, 56, 287-312.

Wells, P., de Lange, P., \& Fieger, P. (2008). Integrating a virtual learning environment into a second-year accounting course: determinants of overall student perception. Accounting \& Finance, 48(3), 503-518.

Wong, L. (2013). Student engagement with online resources and its impact on learning outcomes. Journal of Information Technology Education: Innovations in Practice,, 12, 129-146. Retrieved from http://www.jite.org/documents/Vol12/JITEv12IIPp129-146Wong\%20FT116.pdf

Wong, S. L., \& Hanafi, A. (2007). Gender difffernces in attitutdes towards information technology among Malaysian student teachers: A case study at Universiti Putra Malaysia. Educational Technology and Society, $10(2), 158-169$.

Yau, H. K., \& Cheng, A. L. F. (2012)). Gender difference of confidence in using technology for learning. The Journal of Technology Studies, , 38(2), 74-79. 


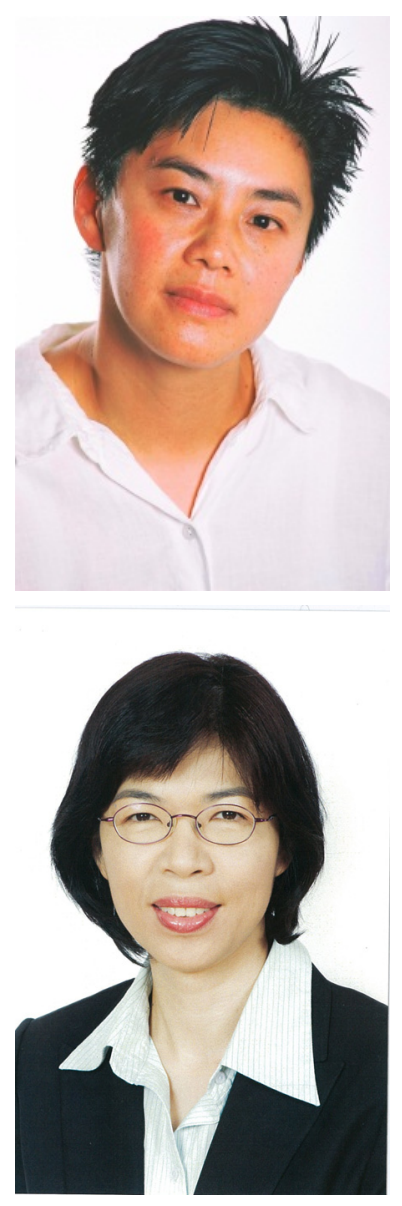

\section{Biographies}

Lily Wong is the Unit Coordinator for Introductory Accounting, one of the largest student cohorts at Victoria University. Since undertaking her $\mathrm{PhD}$, she has been actively involved in the research, development and integration of online teaching resources to improve the student learning experience for first year accounting students. Lily's contribution to teaching and learning has been formally recognised as a recipient of university and national awards. These include the Australian Learning and Teaching Council Citation for Outstanding Contribution to Student Learning; and recipient of the Vice-Chancellor's Peak Award for Excellence in Teaching and Learning.

Dr Michelle W. L. Fong is a Senior Lecturer in the College of Business at Victoria University. She has taught in Australia, China, Malaysia, and Singapore. Prior to her academic and research career, she worked with a range of organizational systems in corporations based in different countries. Her research interest includes finance, online education, information technology applications, and e-business. 